\title{
The Relationship of Empowerment and Job Satisfaction with Productivity of Employees of Education System in Ahwaz
}

\author{
Karim Amir Chehrazi \\ Department of Governmental Management \\ College of Human Science, Saveh Branch, Islamic Azad University, Saveh, Iran \\ Email: k a chehrazi@yahoo.com

\section{Reza Shafizadeh} \\ Department of Governmental Management \\ College of human science, Saveh Branch, Islamic Azad University, Saveh, Iran \\ Email: rsg1189@yahoo.com
}

Doi:10.5296/ ijld.v6i1.8928 URL: http://dx.doi.org/10.5296/ ijld.v6i1.8928

\begin{abstract}
This study was aimed to determine the relationship of empowerment and job satisfaction with productivity of employees in education system in Ahwaz, which was conducted in 2015. The present study was practical in terms of objective, descriptive of correlational type in terms of data collection method. The statistical population of the present study consisted of all the employees in the education organization of region 3 in Ahwaz who had participated in in-service training programs between the years of 2008 and 2013. The population consisted of 300 individuals among whom 169 individuals were selected using the simple random sampling method and the Morgan table; these 169 employees were given questionnaires. The method of collecting data was based on Spriters standard questionnaire of empowerment (1995), Berry Field and Ruth questionnaire of job satisfaction (1951) and standard researcher-made questionnaire of employees' productivity (1995). In the present study, in order to determine the reliability, the Cronbach's Alpha Coefficient was used; the reliability was greater than 0.7 for both types of questionnaires. In addition, in order to determine the validity of the questionnaires, the content validity was used, hence the questionnaires were approved by experts. The analysis of the obtained data from the implementation of the questionnaires was done using SPSS 21 software in two sections of descriptive and inferential (Pearson Correlation and Multiple Regression). The results of the study indicated that there was a relationship of empowerment and its components such as the feeling of competence, feeling of significance, and feeling of being effective with employees'
\end{abstract}


productivity. But there was no relationship between the component of feeling of self-determination and employees' productivity. Moreover, there was a positive and significant relationship between job satisfaction and its components such as ability, understanding and perception of job, organizational support, motivation and feedback with employees' productivity.

Keywords: empowerment, job satisfaction, productivity, feeling of significance, feeling of competence

\section{Introduction}

Historically, humans have always endeavored economically to take the maximum Advantage of resources, obtaining minimum result. The inventions and innovations done by humans, from the most basic tools to the most complex equipment today, have been affected these efforts. If we define resources as things that are found to be useful in meeting humans' needs, we will understand that although there are various resources, they are scarce and limited, whereas humans' needs are limitless and are increasingly becoming greater and greater. Hence, it is extremely important that humans use fewer resources to meet more needs. The significance of this concept has always led humans' creative and thoughtful efforts to the optimal exploitation of resources. Many scientific studies are done in this way (Moshabbaki, 2006).

In every organization, human force is a vital resource which is available. The optimal use of human force is the key to organizations' productivity. Optimization in human force means that we should obtain more favorable results from less human resources by using better management. Optimization must pay more attention to the improvement and enhancement of the status quo than to the creation of novel facilities and new capacities.

In the process of optimization, it has always been tried to evaluate situations in terms of using fewer resources to achieve better results, in order to identify inadequacies and to try to improve them (Bamberger et al, 2014).

The change in the approaches to human resources and the importance of human resources results from a shift from the classical management of human resources to the strategic management of human resources. Hence, in the recent approach, there is an emphasis on the strategic role which human resources can play in increasing organizations' effectiveness (Datta et al, 2005). The main reason why organizations fail to realize their objectives is that they do not effectively use human force (Enshassi, et al, 2007). Hence, Thomas stated that human force's productivity can be defined as the amount of production divided by the number of working hours. In addition it is possible to measure the productivity of human force by using the proportion of the produced income to the whole human force (Sayouyan, 2002). In another definition, the productivity of human force is the sum of human force's effectiveness and efficiency present in a certain working environment (Sharifzadeh and Mohammadi Moghadam, 2009). 
What has always been of interest to psychologists and social scientists is individuals' job satisfaction and its impact on their spirit and productivity. If a person is interested in his job, his creativity and talent will be flourished and less fatigue and exhaustion occurs. On the contrary, if a person is not satisfied with his job, he will experience fatigue and depression, his work will remain inconclusive and the society will suffer consequently. Job satisfaction is one of the most important factors in occupational success and results in elevation of productivity and sense of individual satisfaction. Every employer is somehow trying to increase job satisfaction in his own institution's employees. Job satisfaction is significant and necessary because individuals spend almost half of their waking hours at work (Etienne et al., 2011). On the other hand, the relevant studies indicated that employees with greater job satisfaction are in good shape in terms of physic and intellectual ability and this leads to higher productivity.

Job satisfaction refers to the degree of feeling and positive attitudes which individuals have towards their jobs (Navidian et al., 2014). On other words, job satisfaction is general feeling of people towards their jobs which has a significant impact on individual, social and organizational life and plays an important role in mental and physical health (Nouranipour \& Akbarzadeh Abd-Al-Jabbar, 2011). According to Luck (1969), job satisfaction consisted of four factors: reward means salary and conditions of promotion, professional context means employment conditions and benefits, factors and human relations with colleagues and supervisors, and job features (cited in Rezaian, 2007).

Today, in every organization, in order to empower human force, different methods are used. The empowerment of employees is a novel technique which tries to enhance productivity by raising employees' commitment to their organization and vice versa. This method is a valuable method which creates a balance between the control of management and employees' freedom of action. If management applies control, employees' interests in innovation will be lost, leading to more workload on managers. Hence, employees become reliant on others. Complete freedom can lead to rupture, leading to rework and confusion in duties. This shows that organizational resources are not being used effectively. The empowerment of employees creates a balance between the two above-mentioned elements, putting individual and organizational objectives in the same direction; in line with Synergy of forces and talents, employees believe that the advancement of their organization will be to their benefit (Rahdarpour, et al, 2012).

As mentioned, the empowerment of employees is an effective tool for increasing employees' productivity, and optimal use of individual and group abilities and capacities in line with organizational objectives. Empowerment is defined as the right for employees to make decisions in order to enhance their effectiveness and play useful roles in organizations (Chang and Lio, 2008). According to Spriters, empowerment includes the following components:

Feeling of being effective: The duty which has the characteristic of effectiveness is considered, by individuals, to be the key to realizing duty-based objectives. In other words, individuals must believe that they can play important roles in realizing the set goals.

Competence: Competence is individuals' perceptions of their capabilities to do the assigned 
duties. If duties are such that individuals can do their assigned activities skillfully, they will feel positively efficient.

Feeling of significance: this feeling refers to the value of an occupational purpose based on individuals" ideals and standards. If individuals find their activities to be valuable, their activities will be significant.

Self-determination: This duty refers to employees' freedom of action when choosing what occupational activities to do.

In today's world, Wealth of Nations consisted of physical natural wealth and human wealth, hence educational organizations, as one of the most important, effective and comprehensive organizations, are responsible for people's official education and training. As a fundamental organization, education has benefited from the wealth. Managers and leaders of education systems should try to improve the performance of education system through motivating administrators, teachers, students and parents to cooperate with each other in order to overcome various obstacles in the way of elevation of productivity in education system (Gaven \& Miller, 2005; cited in Hejazi, 2014).

There are variety of factors in the education system of each country which influence the shape, objective and quality of that system. Education is a community which results from communal living and influenced by the social environment. Therefore, education is a social phenomenon. Education system consisted of different components which each of the components plays an important role in the achievement of goals. Teacher, as one of the most significant factors in education, plays a key role in education system and his satisfaction could have considerable impact on realization of achievement of the goals of education system (Tousi \& Sa'ebi, 2002).

On the other hand, education is a key factor of advancement in countries, because the bases and roots of educating creative, trained, and responsible human force, developing societies, are infrastructure in education system. The fact that we have a young and growing population has added to the numbers and proportions of student populations, leading to the extension of education system. Despite the allocation of a big percentage of the country's budget and the presence of a large number of human forces in this system, it is undoubtedly one of the most problematic and busiest parts of the society. Considering the fact that there are inadequacies in terms of physical spaces, human resources, and lab facilities in this system, and the fact it is impossible to solve such problems in the short run, it is best to emphasize the optimal usage of available resources. From the above-mentioned, we only focus on the importance and role of teachers. The recent writing is focused on how we can use the present human forces in education system in a more optimal way, without adding to their numbers. Hence, in the present study, we are trying to find out the relationship of employees' empowerment and job satisfaction with productivity in education system in Ahwaz. The research hypotheses and model are as follows:

\section{Main hypothesis:}

$\mathrm{H}_{\mathrm{a}}$ : There is a relationship between empowerment and job satisfaction with employees' 
productivity in education system of Ahwaz.

Subsidiary hypotheses:

$\mathrm{H}_{\mathrm{b} 1}$ : There is a relationship between feeling of significance and employees' productivity in education system of Ahwaz.

$\mathrm{H}_{\mathrm{b} 2}$ : There is a relationship between feeling of competence and employees' productivity in education system of Ahwaz.

$\mathrm{H}_{\mathrm{b} 3}$ : There is a relationship between self-determination and employees' productivity in education system of Ahwaz.

$\mathrm{H}_{\mathrm{b} 4}$ : There is a relationship between being effective and employees' productivity in education system of Ahwaz.

$\mathrm{H}_{\mathrm{b} 5}$ : There is a relationship between ability and employees' productivity in education system of Ahwaz.

$\mathrm{H}_{\mathrm{b} 6}$ : There is a relationship between understanding and perception of job and employees' productivity in education system of Ahwaz.

$\mathrm{H}_{\mathrm{b} 7}$ : There is a relationship between organizational support and employees' productivity in education system of Ahwaz.

$\mathrm{H}_{\mathrm{b} 8}$ : There is a relationship between motivation and employees' productivity in education system of Ahwaz.

$\mathrm{H}_{\mathrm{b} 9}$ : There is a relationship between feedback and employees' productivity in education system of Ahwaz. 
The conceptual model is presented in figure 1:

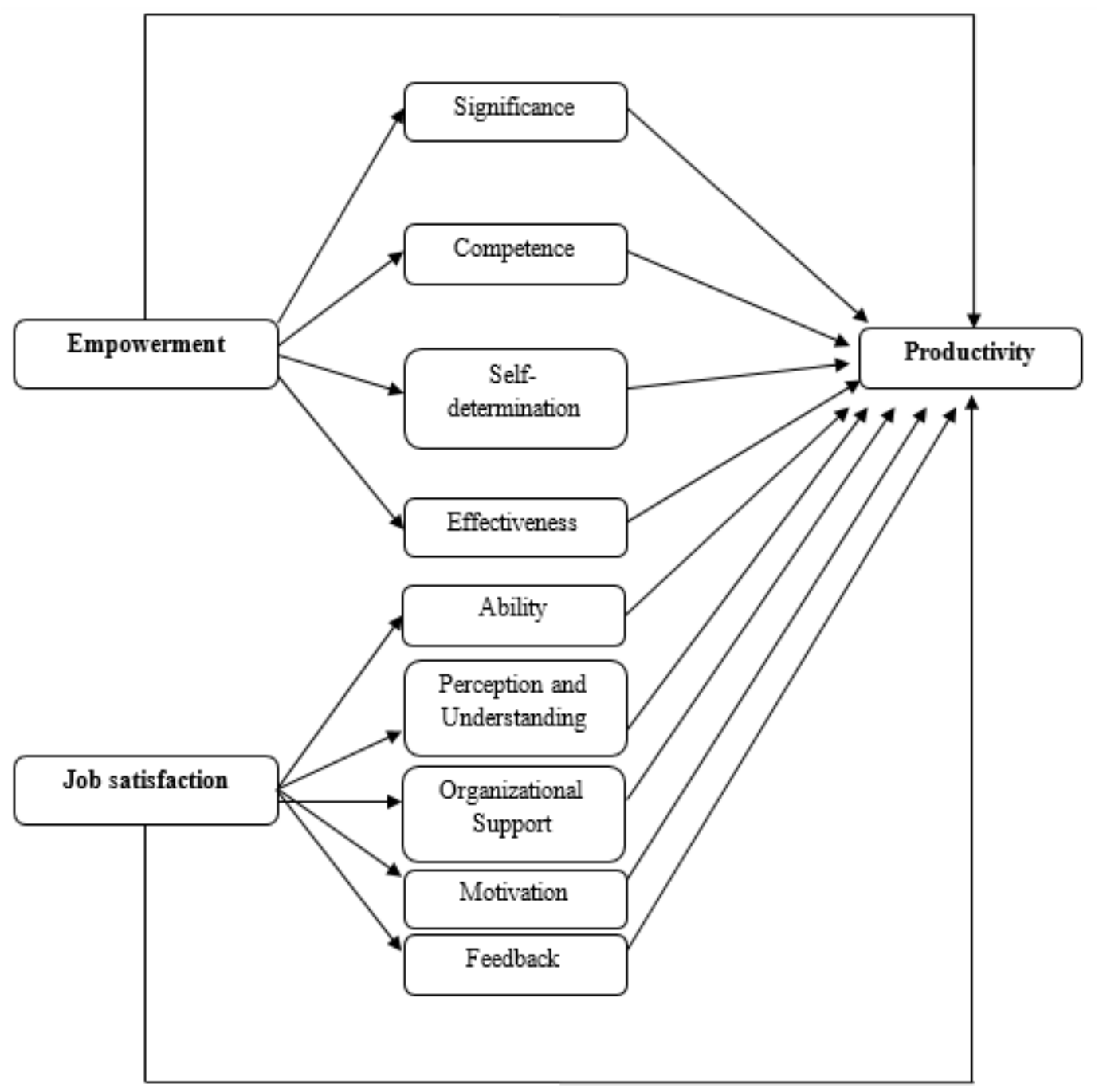

Figure 1: conceptual model of the research

\section{Methodology}

The method of the study is practical in terms of objective; and it is descriptive and correlational in terms of data collection method. In addition, since questionnaires were used, the present study is considered to be quantitative.

The statistical population of the present study consisted of all the employees in the education organization of region 3 in Ahwaz who had participated in in-service training programs between the years of 2008 and 2013. Moreover, there were 300 employees among whom 169 individuals were selected as the study sample using random sampling method and Morgan table.

In this study, questionnaires were used in order to collect data. Specialized questions included questions regarding the empowerment of employees, their job satisfaction and their 


\section{Macrothink}

International Journal of Learning \& Development

ISSN 2164-4063

2016, Vol. 6, No. 1

productivity so that there were 16 questions to evaluate the empowerment of employees and 19 questions to investigate their job satisfaction. All the questions followed 5-point Likert scale (1: very low; 5 : very high). In addition, the next section included 4 questions in order to measure employees' productivity. They also followed 5-point Likert scale (1: completely agree; 5: completely disagree).

The questions concerning the empowerment of employees were designed using Spriters Standard Questionnaire (1995) and Field and Ruth standard questionnaire (1951) were employed in order to design questions in the field of employees' job satisfaction. Moreover, in order to provide and customize employees' productivity questionnaire, a researcher-made questionnaire was used. The table below indicates which variables are determined by the questions.

Table 1: distribution of the items and the calculation of reliability for each of the study variables

\begin{tabular}{|c|c|c|c|}
\hline Dimension & Component and index & Item number & $\begin{array}{l}\text { Reliability } \\
\text { coefficient }\end{array}$ \\
\hline \multirow{4}{*}{$\begin{array}{l}\text { Employees' } \\
\text { empowerment }\end{array}$} & Significance & $1-4$ & 0.725 \\
\hline & Competence & $5-8$ & 0.882 \\
\hline & Self-determination & $9-12$ & 0.896 \\
\hline & effectiveness & $13-16$ & 0.711 \\
\hline \multirow{5}{*}{$\begin{array}{l}\text { Employees' job } \\
\text { satisfaction }\end{array}$} & Ability & $1-3$ & 0.734 \\
\hline & $\begin{array}{l}\text { Understanding and perception } \\
\text { of job }\end{array}$ & $4-7$ & 0.895 \\
\hline & Organizational support & $8-11$ & 0.798 \\
\hline & Motivation & $12-15$ & 0.743 \\
\hline & Feedback & $16-19$ & 0.768 \\
\hline $\begin{array}{l}\text { Employees' } \\
\text { productivity }\end{array}$ & $\begin{array}{l}\text { Reduction in rework; using } \\
\text { skills; reducing errors; } \\
\text { realization of organizational } \\
\text { objectives. }\end{array}$ & $1-4$ & 0.876 \\
\hline
\end{tabular}

In this study, in order to confirm the validity of the questionnaires, face and content validity 
methods were used. Hence, the questionnaire was given to professional individuals, and the face validity of the questionnaire was confirmed. The results of investigation of reliability showed that the Cronbach's Alpha coefficient for the whole questionnaire (39 questions) was equal to 0.87 . The reliability coefficient of the dimensions of the three main structures was greater than 0.7 ; the results are presented in the table above.

The analysis of the data was carried out in two sections: descriptive and inferential. In the first section, demographic data and the descriptive statistics of the variables were given. Then in the next section, in order to examine the hypotheses of the study, the correlation and regression tests were used in the SPSS software.

\section{Findings}

\section{Descriptive Findings}

The findings of the study in the descriptive statistics section (participants' characteristics) showed that most of the participants were men. Most of the sample group consisted of employees who have B.A. degrees. In addition, the respondents were between the ages of 30 to 40 and most of the employees had a work background of more than 20 years.

Results of hypothesis testing

Before testing the hypothesis, normality of data distribution was examined using the Kolmogorov-Smirnov test. The results indicated that since the significance of the variables was greater than 0.05 , the distribution of the research data was normal for all dimensions and components. In the present study, as mentioned, the inferential statistics is allocated to the correlation and regression tests in the SPSS software. The results of the main hypothesis and the subsidiary hypotheses are given in the tables below.

Hypotheses of the study:

There is a relationship between employees' empowerment and its dimensions (sense of significance, sense of competence, sense of self-determination and sense of being effective) with employees' productivity in education system of Ahwaz.

The results of testing the correlation between employees' empowerment and its dimensions with employees' productivity are presented in the table below.

Table 2: results of the test of correlation between employees' empowerment and its dimensions with employees' productivity

\section{Correlation}

Significance

0.001

\section{Pearson correlation coefficient}

Test result

Approved 
$\begin{array}{llll}\text { Competence } & 0.001 & 0.337 & \text { Approved }\end{array}$

$\begin{array}{llll}\text { Self-determination } & 0.367 & 0.037 & \text { Rejected }\end{array}$

$\begin{array}{llll}\text { Effectiveness } & 0.001 & 0.417 & \text { Approved }\end{array}$

Since the significance level in all hypotheses but self-determination was lower than 0.01 , it can be inferred that there is a significant and positive relationship between the components such as significance, competence, and effectiveness with productivity of employees. In addition, the positive sign of the correlation coefficient in the table above shows the direct relationship between variables. This means that with an increase or decrease in one variable, the other will increase or decrease. However, in terms of self-determination, the findings indicated that there is no relationship between this component and employees' productivity, because the significance was greater than 0.05 .

There is a relationship between employees' job satisfaction and its dimensions (ability, understanding and perception of job, organizational support, motivation and feedback) with their productivity in education system of Ahwaz.

Table 3: results of the test of correlation between employees' job satisfaction and its dimensions with employees' productivity

\section{Correlation}

Ability

Understanding and

perception of job

Organizational

support

Motivation

Feedback
0.001

Significance

0.001

0.001

0.001

0.001

\section{Pearson correlation coefficient}

0.413

0.518

0.451

0.498

0.512

\section{Test result}

Approved

Approved

Approved

Approved

According to table above, since the significance level of the correlation test between employees' job satisfaction and their productivity is 0.01 , it can be deduced that there is a significant relationship between the variables at $99 \%$ confidence level. In addition, since the value of correlation coefficient between job satisfaction and productivity is 0.671 (has positive value), it can be expressed that increase in employees' job satisfaction leads to elevation of their productivity. 
Main hypothesis of the research

There is a relationship between empowerment and job satisfaction of employees in education organization of Ahwaz and their productivity.

The hypothesis was investigated using multiple regression test which the results are mentioned in the following tables. Prior to performing calculations, the test assumptions were studied. Assumptions such as linear relationship between the variables (scatter diagram), normality of the error term, independence of the error and linearity, which the results indicated that the test can be used.

Summary of the regression test related to the investigation of the relationship between the variables of empowerment and job satisfaction with employees' productivity is mentioned in table 4.

Table 4. Summary of the regression test related to the investigation of the relationship between the variables of empowerment and job satisfaction with employees' productivity

\begin{tabular}{llllll} 
Model & $\begin{array}{l}\text { Predictor } \\
\text { variables } \\
\text { entered } \\
\text { model }\end{array}$ & Correlation & $\begin{array}{l}\text { Square of } \\
\text { the } \\
\text { coefficient } \\
\text { correlation } \\
\text { coefficient }\end{array}$ & $\begin{array}{l}\text { Modified } \\
\text { correlation }\end{array}$ & $\begin{array}{l}\text { Standard } \\
\text { error of } \\
\text { estimation }\end{array}$ \\
\hline $\mathbf{1}$ & Empowerment & 0.578 & 0.334 & 0.328 & 0.5254 \\
& Job satisfaction & & & &
\end{tabular}

Criterion variable: employees' productivity

The information mentioned in the above table indicates that multiple correlation coefficient between the components of empowerment and job satisfaction and productivity of employees is equal to 0.578 . On other words, the two variables can explain about $33.4 \%$ of the variance of employees' productivity (R2=0.334).

F statistics also indicated that the research regression model, which is consisted of two variables of empowerment and job satisfaction and one criterion variable of employees' productivity, is a significant model since the significance level of 0.000 is less than 0.05 and $(\mathrm{P}=0.000, \mathrm{df}=3, \mathrm{~F}=53.946)$.

Next computer output shows the analysis of regression model.

Table 5. Coefficients of variables of empowerment and job satisfaction in prediction of employees' productivity

$\begin{array}{llllll}\text { Model } & \text { B } & \text { SE } & \text { Beta } & \text { T } & \text { Sig. } \\ \text { y-intercept } & 1.033 & 0.189 & & 5.479 & 0.000\end{array}$


$\begin{array}{llllll}\text { Empowerment } & 0.438 & 0.051 & 0.452 & 8.541 & 0.000\end{array}$

$\begin{array}{llllll}\begin{array}{l}\text { Job } \\ \text { Satisfaction }\end{array} & 0.112 & 0.043 & 0.134 & 2.597 & 0.010\end{array}$

Criterion variable: employees' productivity

The results of the above table indicate that constant and variable coefficients (i.e. y-intercept, empowerment and job satisfaction) are significant at 0.05 level. On other words, y-intercept, empowerment and job satisfaction in the regression model are capable of predicting changes in employees' productivity significantly. Therefore, according to the data mentioned in table 4, the regression model could be as follows.

$\mathrm{Y}=1.033+0.438$ (empowerment) +0.112 (job satisfaction)

In the equation above, "Y" denotes employees' productivity. According to the above regression model, it can be expressed that a unit increase in the components of empowerment and job satisfaction leads to 0.438 and 0.112 unit increase in employees' productivity, respectively.

Beta standardized coefficients are to evaluate the contribution of each predictor variable in the model based on standard deviation. On other words, a unit change in standard deviation of empowerment and job satisfaction results in prediction of the score of employee's productivity, 0.452 and 0.134 , respectively. Moreover, beta coefficient provides the possibility to compare the effects of several predictor variables on criterion variable (employees' productivity). Here, the component of employees' productivity has the maximum impact (0.452).

\section{Discussion and conclusion}

The present study was conducted in order to examine the relationship of empowerment and job satisfaction of employees and their productivity in education system of the city of Ahwaz in 2015. After analysis of the statistical data obtained using the SPSS software, the findings showed that, in general, there is a positive and significant relationship between the empowerment and job satisfaction of employees and their productivity. It was also shown that the more empowered and satisfied the employees, the more productive they become, leading to the effectiveness of organizational activities.

Moreover, many important and significant results were obtained in various fields. For instance, reviewing the literature, it was deduced that today's complicated life is constantly moving towards being new and productivity is considered as life's necessity. Increasing productivity in individuals could lead to promotion of quality and quantity of services, reduction of costs, prevention of waste of resources, reduction of bureaucracy, elevation of competition, enhancement of efficiency and creation of motivation and job satisfaction of employees. Specifically, if teachers want to have high levels of productivity, such conditions 
mentioned in the present research in the context of empowerment and job satisfaction should be provided. There have been several researchers who mentioned to the variables influencing productivity. In addition, it was indicated in the present study that job satisfaction has significant impact on some of organizational variables including productivity. The findings of the research main hypothesis indicated that empowerment and job satisfaction of the employees had significant and positive impact on their productivity. On other words, if reinforcing factors are provided for empowerment and job satisfaction, employees' productivity enhances. The results are in line with previous studies such as Moghimi (2007).

In the following, we investigate the results obtained from this study; generally, the following results were obtained.

This study inferentially showed that there is a relationship between employees' feeling of significance and their productivity in education system of Ahwaz. Hence, the more significance among employees, the more productive they become. This means that if employees value their activities more, their activities will be more significant and more productive. As Sharifzadeh and Mohammadi Moghadam (2009) showed in their studies, there is a relationship between the empowerment of employees and their productivity in Lorestan's enforcement force. Hence, it seems that the results obtained in the present study are in line with the results obtained from other studies.

This study showed that there is a relationship between of employees' feeling of competence and their productivity in the city of Ahwaz. Hence, the more eligible the employees find themselves to be, the more productive they will be. Nosratpanah et al (2012) examined the relationship between working life quality and the productivity of human force in an oil-production company; they showed that having a proper feeling about work conditions can help enhance employees' productivity; hence, it seems that the results obtained from this study are in line with the results obtained from other studies.

The results showed that there is a relationship between employees' feeling of being effective and their productivity in education system of Ahwaz. Hence, if employees believe that they can play an important role in doing their occupational duties, they can enhance their productivity. Vio and Shert (1996) referred to the presence of a relationship between teachers' psychological empowerment and their occupational commitment; they stated that there is a relationship between psychological empowerment and professional growth; hence it seems that the results obtained from this study are logical.

The results indicated that there is a relationship between the empowerment of employees and their productivity in the education system of the city of Ahwaz. In addition, we found that among the factors forming the empowerment of employees, significance has the most effect on employees' productivity; and this factor can be considered as a key factor in the scheduling of human resources.

Based on the findings of the study, the following propositions are presented:

- In service trainings should be effectively carried out within the organization in order for the employees to feel skilled and competent. 
- School administrators should try to increase teachers' job satisfaction in order to increase their productivity more than before. Accordingly, administrators can increase benefits and wages, reduced working hours, give leave of absence, etc. to their employees.

- Individuals with expertise should be recruited.

- Managers, by giving proper feedbacks, must let their employees know that they have been effective in the process of achieving organizational goals.

\section{References}

1. Bamberger, P. A., Biron, M., \& Meshoulam, I. (2014). Human resource strategy: Formulation, implementation, and impact. Routledge.

2. Chang, L. C., \& Liu, C. H. (2008). Employee empowerment, innovative behavior and job productivity of public health nurses: A cross-sectional questionnaire survey. International journal of nursing studies, 45(10), 1442-1448.

3. Datta, D. K., Guthrie, J. P., \& Wright, P. M. (2005). Human resource management and labor productivity: does industry matter? Academy of management Journal, 48(1), 135-145.

4. Enshassi, A., Mohamed, S., Mustafa, Z. A., \& Mayer, P. E. (2007). Factors affecting Labour productivity in building projects in the Gaza Strip. Journal of Civil Engineering and Management, 13(4), 245-254.

5. Etienne, A. M., Dupuis, G., Spitz, E., Lemetayer, F., \& Missotten, P. (2011). The gap concept as a quality of life measure: Validation study of the Child Quality of Life Systemic Inventory. Social indicators research, 100(2), 241-257.

6. Hejazi, M. (2014). Study of the relationship between work ethics and job satisfaction with productivity of teachers in Education Organization of Tehran, M.A. Thesis, Faculty of Psychology, Islamic Azad University, Science and Research Branch.

7. Moghimi, S.M. (2007). Organization of Management and Research Approach, Tehran: Termeh Press.

8. Moshabbaki, A. (2006). Organizational behavior management: practical-value analysis of human behavior, Tehran: Termeh Press.

9. Nouranipour, R.A. \& Akbarzadeh, H. (2011). Study of the relationship between personality traits and job satisfaction of employees of Tabriz Petrochemical Co., Journal of Educational Sciences, Y.4, Issue 14, pp. 25-44.

10. Navidian, A., Saber, S., Rezvani Amin, M. \& Kianian, T. (2014). Correlation between quality of working life and job satisfaction among nurses of hospitals of Kerman University of Medical Science, Journal of Management of Health Promotion, 3(2), pp. 
$7-15$.

11. Nosratpanah, S., Hasani, K. and Yazdi, O. (2012). Study of the relationship between working life quality and productivity of human resources, Journal of HRM in Imam Hossein University, Y. 4, Issue 1, pp. 189-206.

12. Rahdarpour, J., Mohammad Davoudi, Shafi'zedeh, R. and Shoghi, B. (2012). Relationship between organizational justice and productivity of employees. Tehran: Shamim Danesh.

13. Rezaian, A. (2007). Foundation of Organizational Behavior Management, Tehran: SAMT.

14. Sahar Sauian, M. (2002). Labour productivity: an important business strategy in manufacturing. Integrated Manufacturing Systems, 13(6), 435-438.

15. Sharifzadeh, F. and Mohammadi Moghadam, Y. (2009). Relationship between empowerment and productivity of human resources in Lorestan's enforcement force. Journal of researches in law enforcement management, 4(1), pp. 5-18.

16. Spreitzer, G. M. (1995). Psychological empowerment in the workplace: Dimensions, measurement, and validation. Academy of management Journal, 38(5), 1442-1465.

17. Thomas, H. R \& Sakarcan, A. S. (1994). Forecasting labor productivity using factor model. Journal of Construction Engineering and Management, 120(1), 228-239.

18. Tousi, M.A. \& Sa'ebi, M. (2002). Management of Human Resources and Employees, Tehran: Termeh Press.

19. Wu, V., \& Short, P. M. (1996). The relationship of empowerment to teacher job commitment and job satisfaction. Journal of Instructional Psychology. 